ために，肝上清中の $\mathrm{Cd}$ 分布を調べたところ，肝上清中 の Cd の添とえぞが MT 画分中に集積し，MT 量もこ れと嚆応して增加してい忩。乙かし，Se 前投与では MT の誘尊は認められず，ぬた MT 量和上び MT 画分中の Cd 量の增加も認められなかった。このことから，前投 与による肝中 Cd 量の增加は, MT 誘導によって, 上 り多くの Cd が MT と結合したことによると考充られ た. 以上の結果から， $\mathrm{Cu} ， \mathrm{Mn} ， \mathrm{Cr}$ の各前投与飞よっ て Cd の体内分布は変化し，とくに多くの Cd が蓄䅡す る肝中では，そのほとしどが MT と結合したより無害 な状態で存在していることが考光られた。そして，その 結夥 $\mathrm{Cd}$ の全身への移送が抑制され，Cd の急性毒性が 軽減されるもの之考光られ, MT の急性 $\mathrm{Cd}$ 毒性減弱

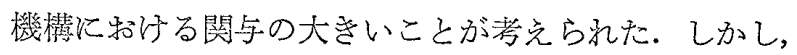
MT を誘導しない Se の前投与による Cd の急性毒㨫減 弱については，これと異なる他の機構の存在が考党られ る.

271. 高濃度カドミウム暴露経験渚の崌発性健康異常 桜井治彦，小野寺及つ子，大前和幸 近藤東郎（慶大医衛生公衛）

過去に高濃度カドミウム $(\mathrm{Cd})$ 暴露を受けた合金作策 者および現在中等度 $\mathrm{Cd}$ 暴露を受けているアルカリ蓄電 池製造作業者について，血中拉よび尿中 $\mathrm{Cd}$ ，多項目腎 機能検查, 血液臨床化学的検査を行ない, 高濃度暴露者 については flow-volume 曲線を中心とする肺換気機能 検查を実施した。

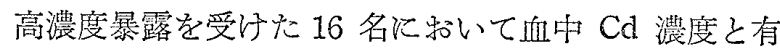
意の正の相関を示した項目は，血清クレアチニン，血清 尿素, 血清 $\beta_{2^{-}}$ミクログロブリン，血清 $\gamma$-グロブリン, 尿の総蛋白, $\beta_{2}$-ミクログロブリン, アミノ酸, 糖, カ ルシウム，銅であり，有意の負の相関を示した項目は， 血液へモグロビン，血清尿酸，血清無機燐，血清アルブ ミン，血清 $A / G$ 比であった。こ和らのデータから数種 の腎クリアランスを計算し，血中 $\mathrm{Cd}$ との相関をみる と,クレアキニンクリアランスと尿素クリアランスは有 意の負の相関示し，腎系球体滤過量の低下があること がわかった：また，尿酸，無機橉，カルシウム，銅では 有意の正の相関を示し，婜尿細管機能の異常があること が示唆された.この 16 名と, 年路命と喫煙量のマッキレ た対照者 20 名について肺換気機能倹查を行なったとこ ろ, 両群の年齢, 身長, 体重, 盁煙量はよく一致し, FVC, FEV 1.0 , PFR, V 25 の平均值はいずれす 8 12\% 程度，暴露群のほうが低い值定示したが，有意の差では なかった、しかし，これらの指標を，同じ方法で測定し た正常者 135 名のデータにより，年齡，体格を，標準化
して, 両群の差を検定すると， FVC と $\mathrm{FEV}_{1.0}$ に有意 の羑が范り， Cd 暴露により肺機能が影響を受けている ことが示された。より低濃度暴露の蓄電池作業者に打い ては腎機能の変化を認めえず，血清 $\beta_{2^{-}}$ミクログロブリ ンの增加と，尿中銅排泄の增加があることが示唆され た。

\section{2。一般住民泳品 $\mathrm{Cd}, \mathrm{Cu} ， \mathrm{Ca} ， \mathbb{P}$ 排泄量} 本多隆文, 小林悦子, 能川浩二 （金沢医大衛生）

Cd 亿よる腎尿細管障害を研究するための基砧资料と して，Cd 中毒に関係与ると思われる柡中無機物 $\mathrm{Cd}$, $\mathrm{Cu}, \mathrm{Ca}, \mathrm{P}$ 濃度裳小児から老人にいたる石川景の $\mathrm{Cd}$ 非污染地域一般住民男 157 名, 女 272 名上り採取したス ポット䐂沉いて謂べた. Cd 敊上び Cu APDC-MIBK 抽出フレームレス原子吸光法, Ca ほ原子 吸光法, Pは Allen 法, クレアチニンは Folin-Wu 法 により，此重はュリコン屈折計で測定した．尿中各浱度 を比重補正檤，クレアチニン補正值，補正しない単純濃 度の 3 通りで表現し，艺の幾何平均叔よび標準偏差を求 め，性，年桷的変動切て钼察した。これらは従来の 知見と大きく矛盾するものでなく，要た分析精度も十分

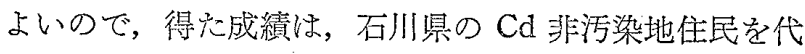
表するものとして十分に利用できるものと考光られた。

座長のむ亡的 $(270 \sim 272)$

野見山一生（自治医大衛生）

いずれる国際的に高い評価を受けてきた研究の一部で あり，中味の豊富な重量感がある説得力のある発表で另 った。 ただ，印刷ミスとは思らが，使用動物 Wistar ラ ットが Wister ラットと記述され充発表が $2 ， 3$ 出り， 論文印刷にあたってはご注意願いたいと思った。

270 : 吉川（岐阜大）は異種金属を微量前投与てて就く と，致死量の金属動物沉投与しても死亡率が低下する ことを報告している.太田ら（肢㚖大）の今回の報告は

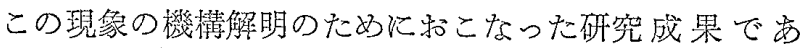
り，明解尔美毫な実験であった，この研究成果は昭和56 年 3 月に米国シンシナチ市で括こなかれた日米共同せミ

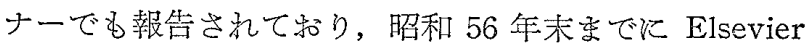
から出版される “Biological Functions of Metallothionein”に卵刷される予定である.

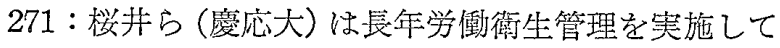
きたカドミウム合金製造（カドミウムフューム）徒事者 そついて疫学的な総合健康調查を実施し，その結果を啹 告した. 原田 (三洋電機) はカドミウム色真製造（カド ミウム粉じん）従事者 3 名に肺機能異常者のみられたこ とを遍加した．今回の報告によれば，カドミウム作業者 
と対照作栄者の肺機能には有意差がないが，年路と身長 で標集化すると肺機能に差がみられるという．今回報告 された工場のカドミウム濃度は肺機能障害を和こす最低 浱度と教克られるので, 今後許容濃度設定のための重 要資料となると考兄られる。赤沶，本研究は昭和 55 年 7 月にブラッセル市で技こなわれた国際中毒学会でる報告 されて数り，すでに Proceedings (Elsevier) K印刷さ れている.

272 : 本多ら (金沢医大) はカドミウム非污染地域住民 のスポット尿中のカドミウム，銅，カルシウム，リン濃 度について報告した。野見山（自治医大）より，1）こ の資料を一般化するためには，食䭒妕のカドゥム， 銅，カルシウム，リンの情報を气兄て和く必要が岉ろ

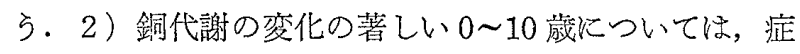
例を追加し，2歳間隔での資料を提供するとたいい几有 用なものとなることが示惨された。

279. 一般住民尿中蛋白, 糖, アミノ酸, プロリン, $\beta_{2}$ - $\mathrm{mG}$ 排泄量

小林悦子, 本多隆文, 能川浩二

\section{【ベリリウム】}

274. ベリリウム工場の健康管理（28）慢胫ベリリウ ム肺の発生要因—ことに暴露ベリリウム化合 物との関逗泾について—

島 正吾, 吉田 勉, 加藤保夫 立川壮一 (保衡大医公衛)

慢情ベリリウム（以下 $\mathrm{Be}$ ) 肺の発生機序に関して, ことに既往に新ける暴露 Be 化合物の種頪・性状と本症 発生との関連性について倹討し，二，三の興味ある知見 完六。

（1）各稫 Be 障害の発生状沉：過去 23 年間に括ける

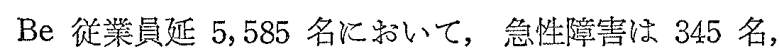
$6.18 \%$ (万ち急性肢炎 27 名, $0.48 \%$ ), 慢性 Be 肺 5 名・0.09\%が発生した。艺だし，1975 年以降で注労衝衛 生管理の充実もあって新規障害例はない。

（2）わが国の慢性 Be 肺 15 例の発生要因：1964 年以 降 4 工場で合計 15 名が発見され，らち 4 名は Be 暴露 歷は明らかでない．また 5 名は常態として Be 举露濃度 は $2 \mu \mathrm{g} / \mathrm{m}^{3}$ 以下の微量暴露環境下にあった. Be 化合物 の種類は全例が $\mathrm{BeO}$, 暴露期間は 1 年 1 月 11 年 2 月, また本症は $\mathrm{Be}$ 暴露中断後数か月～数年学経て発生して いる。

（3）取扱いBe 化合物の種類・性状之発症との関連性 の検討 : 自験例 5 例はいずれるベリリヤ磁器製造 部門
（金沢医大衛生）

Cd による㛑展細管障害を研究するための基碟的資料 として，Cd 中毒に関係すると思われる尿中蛋白，糖，

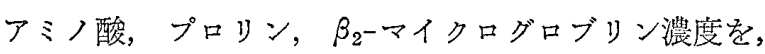
272 と同樣に小罗から老人に至る石川目の $\mathrm{Cd}$ 非污染地 域一般住民男 157 名，女 272 名上り採取したスポット尿 そついて調べた. 蛋白は K-C 変法, 糖は O-TB 法, ア ミノ酸は TNBS 法,プロリンは TNBS-ニンヒドリン 法， $\beta_{2}$-マイクログロブリンはRIA 法にて測定した。尿 中各濃度は, 単純謈度, 此重補正值, クレアチニン補正 值で表わし，艺の幾何平均特よび標準偏差を求め，性， 年龄的な変動について観察した，高龄者で高く，老化と 関係すると思われたのは $\beta_{2}$-マイクログロブリン，就よ び総蛋白量で㘯った。 またこの成績は, 石川県一般住民 の代表值として取り报光るものと考光られた。

〔注〕演題 273 の座長のまとめは次の「ベリリウム」

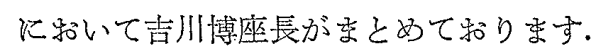

（従業員実数 138 名）に所属し，かつ全員が高純度（99 $\%$ 以上）BeO を常時取り扱う作業従事していた。

從来本症の発生は, $\mathrm{BeO}$ 産生時汇拈ける烺烓温度が 重姴とされ，低温度 $\left(500 \sim 1,000^{\circ} \mathrm{C}\right)$ 煆焼物は, 高温度 $\left(1,500^{\circ} \mathrm{C}\right.$ 以上) 烺焼物にくらべ，ヒ上执よび動物に対 して明らかに毒性がつよいとされてきた。 しかし，今回 のわが国の慢性症例の検討では，先の発生飞かかわる Be 化合物としては，低温度烺烓に加光て $99 \%$ 以上の高 䋗度 $\mathrm{BeO}$ で崩ることがきか子て重要な意義をるつこと が考光られた（ちなみに，通常工業用等侮繁用される BeO は，低温度烺接であるが，純度は $95 \%$ 前後で， これらは普通純 $\mathrm{BeO}$ として报われる).

275. Be 障害の成因に関する実験的研究 (1) beryllium による赤血球蔩渗透王澱弱性と膜成 分の関逎临について

森田邦彦，渡辺清博，落合昭博

石井 明，島 正吾 (名保衛大医公衛) 栗田秀樹（名保衛大医衛生）

$\mathrm{Be}$ 障管成因に関する基礎的実験として $\mathrm{BeCl}_{2}$ そ用い 赤血球膜に及济す影響について，in vitroでの倹討を行 なった。

（実験方法） ペリン加ヒト O 型血液（20２2 歳, 男 子) $\mathrm{K} \mathrm{BeCl}_{2}$ saline solution ( $\left.\mathrm{pH} 3.8 \sim 4.0\right)$ を添加し, 